deliberation. Bargaining can take place within a framework of deliberation that "... facilitates learning and common understanding ..." within the regulative, normative, cognitive and imaginary dimensions (Sorensen and Torfing 2007:9). Planners can encourage participants to create particular shared norms, values, codes, knowledge and sentiments concerning geopark in their negotiations. At the same time, laws, mandates and procedures that govern geopark development in Langkawi should be made clear, reminded and adhered to. The negotiation process may be better facilitated in that way. In simple terms, ideally networks can better facilitate negotiations as everyone should know everyone else in close proximity and contact, and all of them would have and be aware of some common shared hopes, values, ideas, beliefs, knowledge, concepts, norms and others concerning geopark development and benefits while playing their formal roles and responsibilities. If they do not, then planners may evoke and highlight the commonalities to the participants and argue for their significance in geopark context. In short, planning consultations based on networks technique would encourage a new form of public governance of Langkawi Geopark that emphasises more on public-private partnerships and networks; less command and control on the part of the government; an integration of horizontal and vertical relationships; steering and facilitating state roles; relative autonomy and empowerment for all stakeholders; and negotiation, persuasion and collaboration and not just the usual top-down coordination (see Ingraham and Lynn 2004, Francesch-Huidobro 2008, Kjaer 2004, Kooiman 2007 and Sorensen and Torfing 2007 on new definitions of governance, public governance and networks governance).

In the consultation of any geopark event or activity, planners may already know the formal roles and functions of the governmental participants in the consultations. However, perhaps the new networks between them and the participants may give them the opportunity to sit down, discuss and identify together any overlapping roles or functions detrimental to geopark development and clearly identify roles and functions that can be effectively integrated and synchronised for geopark development while not omitting them altogether. That task may not be difficult if there would have been frequent and regular meetings and interactions, and creation of norms and values on closeness of relationships and personal familiarity, from the beginning to the end of the consultation and networking process. In fact, the authors and their team members learned from their interviews that some of the stakeholders involved in the carnival and conference were already familiar with one another and have worked with one another before. Hence, newly established networks may allow the planners and consultation participants to better negotiate, bargain and even comfortably persuade one another without or with less animosity concerning the nature of role and functions overlap and integration. Through the networks, the planners may better communicate key geopark (i.e. heritage conservation and sustainable development) principles such as environmental protection, resource conversation, quality of life, intergenerational obligations, social justice and the significance of participation for development to all the participants. Convincing 
participants of the importance of geopark principles will not be stressful and challenging due to potentially evoked similar mindsets, norms, values, beliefs concerning Langkawi Geopark significance among the networked participants.

\section{LESSON FROM SIMILARITIES}

Once the networks have been established, they need to be maintained and stabilised. To do that, planners can urge for many more frequent meetings (face-to-face if possible) between the participants throughout the planning process, and consequently, in managing and implementing the activities. The networks ought to be constantly interactive and on-going. The Geopark Carnival and Geopark Conference as exampled demonstrated that most of the participants always attended meetings conducted by LADA, prior and during the activities. Frequent interactions definitely occurred between them. In fact, such frequent interactions and meetings can serve as a good lesson in networking for future planning of other geopark projects. Planners can learn from the achieved benefits of such interactions and networking. In any networks established through consultations, frequency of meetings and on-going interactions may be sustained depending on patterns of similarities or commonalities between the participants that planners can identify and draw out during the consultation process, for example, similar values (cultural or social), beliefs, knowledge, norms, viewpoints, mindsets, and sentiments concerning geopark development. As noted earlier, some patterns of similar ideas, knowledge and awareness about geopark concept and benefits were discovered from the informants and respondents of the studies. These may be drawn out to evoke a strong sense of similarities among the stakeholders that would convince them to see the importance of their similarities for effective networking, and consequently, effective work cooperation and success of future geopark activities. Planners could even make the effort to evoke a strong (or stronger) sense of belonging and 'geoparkian' identity among the stakeholders. Findings from semi-structured interviews with some local Langkawians uncovered that a strong sense of geoparkian identity has already existed among them (see Ong 2010b). This feeling can be further fostered and spread through potential networks among many other local people and authorities who could be involved in future geopark development projects.

In the Geopark Carnival and Geopark Conference examples, at the cognitive level, the stakeholders projected similar viewpoints concerning their understanding of the meaning of geopark, and awareness of the importance of the geopark status to Langkawi socio-economic development, geological heritage conservation, ecological heritage conservation, and to socio-cultural heritage conservation in Langkawi. That had a positive impact on their work cooperation. They also demonstrated particular similar behavioural orientations depicting positive work attitude in terms of cooperation. For instance, most of the stakeholders made similar efforts to understand the information and messages conveyed by the organiser, and to always communicate with the main 
organiser, always refer and contact LADA in case of doubts or problems about the activity, and finally, always comply and follow LADA's work orders. These would be the work norms and related values that emerged in both activities and had led to positive work motivation and cooperation. As noted earlier, mutual moral support was also confirmed to be present among some stakeholders and even social cohesion that was indicated by the intensity, density and interactiveness of the work relationships. In future planning of geopark activities, planners may learn from the carnival and conference to develop those similarities at the normative, cognitive and emotive levels, develop relevant social norms and values, and then 'use' them as a mechanism to develop new work networks and ensure cooperation and commitment from every participating stakeholder.

Through any networks created from geopark activity, planners may also learn about how the stakeholders get on with their daily lives and activities, e.g. how they do things effectively in their own ways, how they communicate among themselves, and how they may networked between themselves in everyday lives. Trust, a social value at the communal level, may have already existed among those people on a daily basis prior to any planning consultations or face-to-face meetings or geopark involvement. As mentioned earlier, some of the stakeholders already know one another on a work and personal basis prior to their involvement in the carnival and conference. Some of them may be friends, neighbours or even relatives. Nonetheless, the power of social networks in daily communal and organisational lives may still be uncovered, learned and utilised by the planners in their consultations with those people, especially in their efforts to encourage new networks formation and maintenance among them. Examples of potentially effective social networks are friendship networks, family ties, religionbased ties, village networks, neighbour networks, old school networks, club membership networks and others. The already existing social networks among the stakeholders may become a means to maintain, stabilise and even strengthen their new work relationships and networks in future involvement in geopark activities. For effective networks maintenance and stability, the informal networks and their cognitive, normative and imaginary dimensions maybe as effective as the formal bases normally based on formal organisational roles, positions and public sector obligation, and rules and regulations. If those people are to be involved in new geopark activities and their mutual trust already known to the planners, the planners may then know what to do and how to cement their new work relationships to bring about successful planning and implementation of new geopark activity or project. The planners may just need to further strengthen the trust between the stakeholders throughout the planning process. Even better work commitment may be ensured; social cohesion better still.

Still on the subject of trust, in the Geopark Carnival and Geopark Conference cases, its presence between LADA and some stakeholders was indicated through the participation of similar stakeholders in both the Geopark Carnival and Geopark Conference activities, 
such as LADA, Majpeda, Pejda, Podiram, Watedip, Latga, Lata and Mahot. Of course, one can argue that Majpeda, Pejda, Podiram and Watdip ought to be involved in the geopark activities by virtue of them being local authorities and government agencies performing their work responsibilities and public duties. However, it can be assumed that trust may have already existed between them and LADA considering the frequency of their meetings and interactions in various different geopark activities in the past, as discovered by the authors in their interviews and analysis of both the activities. In both activities and many others not cited in this article, trust may have acted as a social capital that may have contributed to those activities' past successful implementation. In general, planners can regard trust as a social capital for future effective planning and implementation of geopark activities, and for the same stakeholders and others to continue coming together to carry out new geopark activities and projects effectively and successfully.

\section{RECIPROCITY, MUTUALITY AND EXCHANGE}

Once new networks are established through geopark activities consultations, they may allow the interacting planners and stakeholders to exchange resources such as information, knowledge, ideas, and others that are important to get the activities going. Norms and values relating to reciprocity and mutuality would then be assured in the networks. Exchange of resources between LADA and the stakeholders in both the Geopark Carnival and Geopark Conference activities was undoubtedly present, more so through the professed frequent meetings and interactions between them throughout the planning, managing and implementing processes. Planners can learn from these two examples, i.e. to incorporate stakeholder exchange behaviour in their planning of geopark activities, at best to further increase the flow and content of resource exchange relevant to geopark development. Ideally, if any resource exchange were to take place through networks of planners and participants, the planners can better communicate their planning intentions, goals, strategies, perceived effects of the plans and problem solving to the stakeholders through the networked participants throughout the planning process. Instead of forecasting and imagining potential problems and challenges independent of a social context, the planners may be able to identify signs of problems and challenges right from the beginning of the planning stage and plan appropriate action to counter them.

To elaborate on more networks qualities, planners may learn even more about the structural positions of the actors in the networks and make the most out of that. They may learn to identify who are important or central persons or potentially important persons in the networks, who can become good channels of communication, who can bridge links between people, which top level person can communicate and get along with lower level people, who is dominant in the networks, who is influential and powerful in the 
networks, cliques found in the networks, what connects the cliques, who can establish social cohesion, who is the trouble maker or destructive to the networks, who can resolve conflict, and others. In the Geopark Carnival and Geopark Conference examples, key networks actors identified would be LADA, Majpeda and Pejda by virtue of their main positions as Federal Government agencies (LADA) and key local authorities (Majpeda and Pejda) in charge of socio-economic development in Langkawi, specifically the geopark. In terms of their active participation in the geopark activities and high motivation for involvement and frequent attendance of meetings, Lata and Latga also seem to be key NGOs networks actors from the non-governmental side.

\section{CONCLUSION}

This article has introduced networks as a technique in the planning of Langkawi Geopark activities, e.g. in development planning activities, community activities, social events, projects, conference events and others. A study of some geopark activities and stakeholder interview data has revealed the presence of work relationships between some public and private stakeholders who participated in the activities. The relationships led to the successful completion of the activities. Interestingly, some features of the relationships indicated some semblance to certain characteristics of networks of relationships and have the potential to be developed into effective future networks of relationships. The findings have thus offered an early argument on the feasibility of networks as a normed technique for effective governing of future geopark activities, including land use planning. Relevant authorities, policy makers, managers, administrators and planners could consider developing stakeholder relationships into actual networks in their future planning consultations for the planning and implementation of new development activities in Langkawi Geopark.

\section{REFERENCES}

Barney, Darin. 2004. The Network Society. Cambridge, UK: Polity Press.

Bengs, Christer. Year unknown. Planning Theory for the Naive? European Journal of Spatial Development. http://www.nordregio.se/EJSD/debate050718.pdf. 13 September 2011.

Berke, Philip and Manta, Maria. 1999. Planning for Sustainable Development: Measuring Progress in Plans. Lincoln Institute of Land Policy Working Paper. http:// www.lincolninst.edu/pubs/pub-detail.asp?id $=58$.

Burt, Ronald, S. 2010. Neighbor Networks: Competitive Advantage Local and Personal. Oxford: Oxford University Press. 
Chan, Geraldine and Mohamad Zaki Ibrahim. 2008. Conceptualising Network Society in Malaysia. Asian Journal of Social Science, 36, 5.

Chan Kim Ling@ Geraldine, Sarah Aziz, Halimaton Saadiah Hashim and Rahimah Abdul Aziz. 2010. Sistem Jaringan Governans untuk Langkawi Geopark: Pengkisahan Konseptual (trans. Langkawi Geopark Governance Network System: A Conceptual Rubric). Akademika, 80, Sept-Dis. 69-84.

Chan Kim Ling@ Geraldine. 2009. Social Capital and Social Networks in the Malaysian Corporate Elite World: A Conceptual Framework. Jurnal E-Bangi, 4(1), 30-45.

Chan Kim Ling@ Geraldine. 2008. Jaringan Elit Korporat dan Cabaran Sosio-Budaya di Malaysia: Senario pada Awal dan Pertengahan 1990an (trans. Corporate Elite Network and Socio-Culture Challenges in Malaysia: Scenario in Early and Mid 1990s). In Transformasi Masyarakat Malaysia: Cabaran Famili, Gender dan Sosiobudaya (trans.Transforming Malaysian Society: Family Gender and Socio-Culture Challenges). Rahimah Abdul Aziz. ed. Bangi: Penerbit UKM.

Chan Kim Ling @ Geraldine. 2007. Mengkonseptualisasi Modal Sosial dan Pengorganisasian Elit Korporat Malaysia: Satu Kes untuk Memahami Indonesia? (trans. Conceptualising Social Capital and Malaysia Corporate Elite Organisation). In Indonesia dan Malaysia dalam Era Globalisasi dan Lokalisasi: Mewujudkan Kemakmuran Bersama (trans. Indonesia and Malaysia in Globalization Era and Localization). Armida S. Alisjahbana, Ramdan Panigoro, Parikesit, Abd Hair Awang, Chan Kim Ling @ Geraldine, Junaenah Sulehan, Nik Hairi Omar, Shaiful Bahri Md. Radzi, Ruzy Suliza Hashim and Zarina Othman, eds. Vol 1. Bandung: Universitas Padjadjaran.

Chan Kim Ling@ Geraldine. 2004. Business-Politics Relations in Malaysia: A Sociological Analysis of Interlocking Directorships. Unpublished Ph.D. Thesis. London School of Economics and Political Science.

Chan Kim Ling@ Geraldine. 2004. Social Organisation of the Business Elite and Big Business Growth: Malaysia during the 1990s Economic Boom. Akademika, 65, Julai, 69-90.

Christakis, Nicholas A. and Fowler, James, H. 2009. Connected: The Surprising Power of Our Social Networks and How They Shape Our Lives. New York: Little, Brown and Company.

Field, John. 2003. Social Capital. London: Routledge.

Francesch-Huidobro, Maria. 2008. Governance, Politics and the Environment: A Singapore Study. Singapore: Institute of Southeast Asian Studies.

Galloway, Thomas D. and Mahayni, Riad G. 1977. Planning Theory in Retrospect: The Process of Paradigm Change. Journal of the American Planning Association, 43(1). Granovetter, Mark. 1973. The Strength of Weak Ties. American Journal of Sociology $78,1360-80$. 
Halimaton Saadiah Hashim, Rahimah Abdul Aziz, Sarah Aziz and Chan Kim Ling @ Geraldine. 2010. Governans untuk Geopark: Langkawi sebagai Acuan (trans. Governance for Geopark: Langkawi as a Model). Akademika, 80, Sept-Dis., 39-54. Hudson, Barclay M. 1979. Comparison of Current Planning Theories: Counterparts and Contradictions. APA Journal, October. http://classweb-gmu-edu/erodger1/prls\%20 531/hudson.pdf (13 September 2011).

Ibrahim Komoo. 2010. Geopark sebagai Peraga Pembangunan Lestari Wilayah (trans. Geopark as Regional Sustainable Development Model). Simposium Kebangsaan Warisan dan Pemuliharaan (trans. National Heritage and Conservation Symposium). Organised by the Heritage and Conservation Research Group, 26-28 February 2010, Awana Porto Malai, Langkawi.

Ibrahim Komoo. 2004. Geoheritage Conservation and Its Potential for Geopark Development in Asia-Oceania. In Warisan Geologi Malaysia (trans. Malaysia Geological Heritage), Mohd Shafeea Leman and Ibrahim Komoo, eds. Bangi: LESTARI, UKM.

Ingraham, Patricia, W. and Lynn, Laurence E., eds. 2004. The Art of Governance: Analyzing Management and Administration. Washington D.C.: Georgetown University Press.

Kapferer, Bruce. 1972. Strategy and Transaction in an African Factory. Manchester: Manchester University Press.

Kemp, Rene and Parto, Saeed. 2005. Governance for Sustainable Development: Moving from Theory to Practice. International Journal of Sustainable Development, 8, Nos. 1/2. http://kemp.unu-merit.nl/pdf/IJSD\%208(1)\%2002\%20Kemp\%20et\%20al.pdf (10 October 2010).

Kilduff, Martin and Tsai, Wenpin. 2005. Social Networks and Organizations. London: Sage Publications.

Knoke, David and Kuklinski, James H. 1980. Network Analysis. Newbury Park, California: United States of America.

Kooiman, Jan. 2007. Governing as Governance. London: SAGE Publications.

Kjaer, Anne Mette. 2004. Governance. Cambridge, UK: Polity.

Lembaga Pembangunan Langkawi . 2006. Laporan Tahunan 2006 (trans. Annual Report 2006). Langkawi: Lembaga Pembangunan Langkawi.

Lembaga Pembangunan Langkawi. 2007. Laporan Tahunan 2007 (trans. Annual Report 2007). Langkawi: Lembaga Pembangunan Langkawi.

Lembaga Pembangunan Langkawi. 2008. Laporan Tahunan 2008 (trans. Annual Report 2008). Langkawi: Lembaga Pembangunan Langkawi.

Lembaga Pembangunan Langkawi. 2009. Laporan Tahunan 2009 (trans. Annual Report 2009. Langkawi: Lembaga Pembangunan Langkawi.

Mayo, Elton. 1933. The human problems of an industrial civilisation. New York: MacMillan. 
Mercer, Colin. 2003. From Indicators to Governance to the Mainstream: Tools for Cultural Policy and Citizenship. Paper prepared for Accounting for Culture: Examining the Building Blocks of Cultural Citizenship.

Mohamad Zaki Ibrahim and Chan Kim Ling@ Geraldine. 2007. Menjambat Jurang Digital dan Pembentukan Masyarakat Jaringan di Malaysia: Pengkisahan Konseptual dan Empirikal (trans. Bridging Digital Gap and Network Society Formation in Malaysia: Empirical and Conceptual Anecdote). In Ke-Arah Pembangunan E-Malaysia: Isu dan Cabaran (trans. Towards E-Malaysia Development: Issues and Challenges), Norizan Abdul Razak, Zaini Amir, Norwati Md.Yusof and Habibah Ahmad, eds. UKM: Fakulti Sains Sosial dan Kemanusiaan UKM.

Mohd Shafeea Leman, Kamarulzaman Abdul Ghani, Ibrahim Komoo and Norhayati Ahmad. eds. 2007. Langkawi Geopark. Bangi: LESTARI \& LADA.

Ong, Puay Liu and Sharina Abdul Halim. 2010a. Trilogy in Geopark Governance: The Geo, the Bio and the Anthropos. Simposium Kebangsaan Warisan dan Pemuliharaan (trans. National Heritage and Conservation Symposium). Organised by the Heritage and Conservation Research Group, 26-28 February, Awana Porto Malai, Langkawi. Ong, Puay Liu, Sharina Abdul Halim, Ibrahim Komoo, Rahimah Abdul Aziz, Norzaini Azman, Sarah Aziz, Geraldine Chan, Halimaton Saadiah Hashim and Ruslin Amir. 2010b. Langkawi Geopark and The Making of 'Geoparkians' Out of Langkawians: Experience from Within. Simposium Kebangsaan Warisan dan Pemuliharaan (trans. National Heritage and Conservation Symposium). Organised by the Heritage and Conservation Research Group, 26-28 February, Awana Porto Malai, Langkawi. Rahimah Abdul Aziz. 2011. Local Understanding and Acceptance of Geopark Concept and Heritage Conservation: The Langkawian Perspective. Simposium Kebangsaan Warisan dan Pemuliharaan (trans. Symposium on National Heritage and Conservation). Organised by Arus Perdana Project Geopark Sebagai Peraga Pembangunan Lestari Wilayah (trans. Geopark as Regional Sustainable Development Model), with the cooperation of Mineral and Geoscience Department Sarawak and Malaysia University Sarawak (UNIMAS), 29 April - 1 May 2011, Hotel Grand Margherita, Kuching, Sarawak.

Rahimah Abdul Aziz, Halimaton Saadiah Hashim, Ong Puay Liu, Chan Geraldine, Sarah Aziz, Sharina Abdul Halim and Ibrahim Komoo. 2010. Framing Research for Geopark Governance: Using the Situational Analysis Approach. Simposium Kebangsaan Warisan dan Pemuliharaan (trans. National Heritage and Conservation Symposium). Organised by the Heritage and Conservation Research Group, 26-28 February, Awana Porto Malai, Langkawi.

Rahimah Abdul Aziz. 2008. Kepentingan Governans dan Pendidikan untuk Pemuliharaan Warisan (trans. Importance of Governance and Education for Heritage Conservation). In Dialog Governans dan Pendidikan Pemuliharaan Warisan: Istilah, Konsep dan Konteks (trans. Dialogue on Governance and Education for Heritage Conservation: Terms, Concepts and Context). Rahimah Abdul Aziz and Sarah Aziz Abdul Ghani Aziz, eds. Bangi: LESTARI. 
Rhodes, R.A.W. 2003. Understanding Governance: Policy Networks, Governance, Reflexivity and Accountability. Maidenhead, Berkshire: Open University Press.

Rittel, Horst W.J. and Webber, Melvin M. 1973. Dilemmas in a General Theory of Planning. Policy Sciences, 4, 155-169.

Sarah Aziz. 2010. Options for a Legislative Framework for Langkawi Geopark Governance. Simposium Kebangsaan Warisan dan Pemuliharaan (trans. National Heritage and Conservation Symposium). Organised by the Heritage and Conservation Research Group, 26-28 February, Awana Porto Malai, Langkawi.

Scott, John. 1991. Social Network Analysis: A Handbook. London: SAGE Publications. Sharina Abdul Halim, Ong Puay Liu, Norzaini Azman, Ibrahim Komoo, Rahimah Abdul Aziz, Sarah Aziz, Geraldine Chan, Halimaton Saadiah Hashim and Ruslin Amir. 2010. Understanding the Meaning of Geopark and Heritage Conservation from Local Perspectives: Views from Two Fishing Villages in Langkawi, Kedah, Malaysia. Simposium Kebangsaan Warisan dan Pemuliharaan (trans. National Heritage and Conservation Symposium). Organised by the Heritage and Conservation Research Group, 26-28 February, Awana Porto Malai, Langkawi.

Shipley, Robert and Kovacs, Jason. 2005. Principles for the Governance of Heritage Conservation Sector in Canada: Lessons from International Experience. Paper presented for The Historic Places Program Branch, National Heritage Sites Directorate Parks Canada. http://www.environment.uwaterloo.ca/research/hrc/ research/governanceforheritage.pdf (10 Oktober 2010).

Sorensen, Eva and Torfing, Jacob. 2007. eds. Theories of Democratic Network Governance. Basingstoke. Hampshire: Palgrave Macmillan.

Stiftel, Bruce. 2000. Planning Theory. In the National AICP Examination Preparation Course Guidebook, Pelesayed, Roshi, ed. Washington D.C.: Am. Inst.Cert. Planners. http://mailer.fsu.edu/bstiftel/STIFTEL_AICP_Planning _Theory_chapter.pdf. (13 September 2011).

Thomas, Kurian and Bendapudi, Ramkumar. Year unknown. Participatory Planning. http://www.sasanet.org/documents/Tools/Participatory\%20Planning.pdf September 2011).

Wasserman, Stanley and Faust, Katherine. 1994. Social Network Analysis: Methods and Applications. Cambridge UK: Cambridge University Press.

The World Bank. 1991. Managing Development: The Governance Dimension. A Discussion Paper August 29, Washington, D.C: The World Bank. http://www-wds. worldbank.org/external/default/WDSContentServer/WDSP/IB/2006/03/07/000090 341_20060307104630/Rendered/PDF/34899.pdf (10 October 2010).

United Nations Economic and Social Council. 2006. Definitions of Basic Concepts and Terminologies in Governance and Public Administration. Committee of Experts on Public Adminstration, Fifth Session, New York, 27-31 March 2006, Agenda item 5. http://unpan1.un.org/intradoc/groups/public/documents/un/unpan022332.pdf (10 October 2010). 
UNWCED. 1987. Our Common Future. United Nations World Commission on Environment and Development (WCED).

UNDP. 1997. Governance for Sustainable Human Development. A UNDP policy document. http://mirror.undp.org.magnet/policy (10 October 2010).

\section{UNPA GLOSSARY.}

http:/www.unpan.org/Directories/UNPublicAdministrationGlossary/tabid/928/ language/en-US/Default.aspx (10 October 2010).

http://www.globaLangkawi Geoparkeopark.org/publish/portal1/tab59/ (13 October 2009).

http://www.lada.gov.my/index.php?option=com_content\&view=article\&id=44:joomlasecurity-strike-team\&catid=29:the-cms. (13 October 2009).

http://www.lada.gov.my/index.php?option=com_content\&view=article\&id=44:joomlasecurity-strike-team\&catid=29:the-cms. (13 Oct 2009).

http://public.wsu.edu/ susdev/WCED87.html (23 September 2011). 


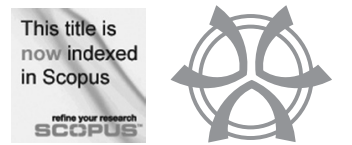

\title{
PARTICIPATION TOWARDS HERITAGE CONSERVATION: CASE OF A FISHING COMMUNITY IN LANGKAWI GEOPARK
}

\author{
Sharina Abdul Halim ${ }^{1}$ \\ Institute for Environment and Development (LESTARI) \\ UNIVERSITI KEBANGSAAN MALAYSIA
}

Ong Puay Liu ${ }^{2}$

Institute of Ethnic Studies (KITA)

UNIVERSITI KEBANGSAAN MALAYSIA

Nurhafizah Yussof ${ }^{3}$

Faculty of Social Sciences and Humanities

UNIVERSITI KEBANGSAAN MALAYSIA

\author{
Lim Choun Sian ${ }^{4}$ \\ South East Asia Disaster Prevention Research Institute (SEADPRI) \\ UNIVERSITI KEBANGSAAN MALAYSIA
}

\begin{abstract}
There is an increasing movement towards acceptance of public participation as a logical approach to heritage conservation and sustainable use of natural resources. In conservation initiatives, to ensure effective participation is to see it as a social process. Thus, the importance of community participation and consultation in planning for heritage conservation is emphasised using an example from fishing community involvement in community-based fisheries management in Langkawi. The setting up of cooperative community resource management Komuniti Pengurusan Ekosistem Perikanan (KPEP)
\end{abstract}

\footnotetext{
${ }^{1}$ Fellow, Institute for Environment and Development (LESTARI), Universiti Kebangsaan Malaysia, 43600, UKM Bangi, Selangor, Malaysia. e-mail: sharinahalim@gmail.com

${ }^{2}$ Professor, Deputy Director, Institute of Ethnic Studies (KITA), Universiti Kebangsaan Malaysia, 43600 UKM Bangi, Selangor, Malaysia. e-mail: puayliu@yahoo.com

${ }^{3}$ Tutor, School of Social, Development and Environmental Studies, Faculty of Social Sciences and Humanities, Universiti Kebangsaan Malaysia, 43600 Bangi, Selangor, Malaysia. e-mail: nur_ hafizah@ukm.my

${ }^{4}$ Research Officer, South East Asia Disaster Prevention Research Institute (SEADPRI), Universiti Kebangsaan Malaysia, 43600 Bangi, Selangor, Malaysia
} 
is a significant attempt that acknowledges the value of local involvement in natural resource management. It aims to understand local fishers' participation in resource management activities towards heritage conservation. One of the findings revealed that although the resource management activities did not mentioned explicitly the importance of heritage conservation. However it could be assumed that intention for heritage conservation is at the heart of the initiatives. Implicit in such an approach is a sense that local fishers' participation in managing resources would utilise local knowledge gained from past down traditions of previous generations. The application of local knowledge encourages them to become aware of their fishing cultural heritage and to encourage them to conserve it. It is crucial for development activities surrounding the area of KPEP Kuala Teriang are compatible and complementary to the existing activities of fisheries heritage conservation and promotion of social well-being.

Keywords: Langkawi Geopark, public/community participation, heritage conservation, community-based fisheries.

\section{INTRODUCTION}

The importance of community participation throughout the decision-making, implementation and enforcement processes has gained recognition among policy makers and planners (Goodwin 1998). The realisation stemmed from the concern over the inability of development projects to achieve its targets due to the lack of attention in ensuring holistic participation among stakeholders (Rahnema 1992). At the same time, there has been an increased focus on building partnerships among stakeholders at different institutional and society levels as an attempt to move away from simple form of consultation to more participatory and collaborative resource management (Izurieta 2007).

In conservation initiatives, to ensure effective participation is to see participation as a social process. Participation as a social process means communicating and working together in groups and with different people in order to achieve common goals as well as learning and sharing from each other's experiences. However, it is important to note that both conservation and participation are concepts and physical practices that are matters of contest and interpretation between policy and social actors (Goodwin 1998:483). There is an implicit assumption by conservation organisations that local people and conservation professionals have shared expectations surrounding the informing ideas, organisational form and subsequent outcomes of local participation. Thus, to ensure success in participatory conservation initiatives is to ensure that "people have the institutional framework and resources required to act upon the knowledge they generate and receive, and to be heard as well as consulted' (Goodwin 1998:495). In this article, the importance of community participation and consultation in planning for heritage 